\title{
COMPETENCE TO THE LEADERSHIP AND IT'S CONCEPT IN THE ARMY OF CZECH REPUBLIC
}

\author{
Zdeněk MIKULKA, Ivana NEKVAPILOVÁ, Roman POSPÍŠIL
}

\author{
University of Defence, Brno, The Czech Republic \\ zdenek.mikulka@unob.cz, ivana.nekvapilova@unob.cz, roman.pospisil@unob.cz
}

\begin{abstract}
The performance of commanding roles in non-standard situations and cooperation within NATO troops showed the need for the development of leadership skills among the commanders of the Army of the Czech Republic at all levels of command. The competence to lead people hasn't been yet systematically developed and explored in the Czech Army. It lacks not only a precise definition for the role of commander but also specifications for each level of command. The aim of this article is to inform about the initial approach to the concept of competence to lead people in the Czech Army, to generate the structure of given competence and a description of its sub-skills for the position of team and platoon from the available theoretical sources. To compare the theoretical model with the results of the research among selected military professionals, which will permit to more accurately identify, for the military experience, necessary elements of competence. The results will be usable for following internal differentiation of the researched competence for other levels of command. This article was written as a part of the project Development of social competencies of the military leader.
\end{abstract}

\section{Keywords: competence for leadership, social competence, leadership}

\section{Preface}

In this contribution, the authors deal with soft skills problematics in conditions of the Army of the Czech Republic (ACR), specifically the competencies to leadership, mostly related to the interpersonal abilities and skills of commanders.

Due to the fact, that the commander in the preparation and conduct of military activities fulfils roles that go beyond the role of a manager, the competence for leadership should not be absent in its list of competencies. For a military organization, it is typically a cooperative action of military teams that have advanced reconnaissance, weapons, communications, logistics and many other systems. Therefore, commanders must be highly qualified and also technically as well as organizationally capable. These capabilities are far from being enough because the people who are part of these teams constitute a wide spectrum of personalities of a various qualities. Managing the requirements resulting from one's own commander role, including the skills to lead a team of subordinates, and, highly qualified specialists, places an extraordinary demand on the commander's personality and constitutes one of the key prerequisites for their success.

In the ACR there has not been a profile of such successful commanders created yet not even in terms of professional specialization, nor by the commander's levels classification and responsibility. There also no adequate methods to achieve this skill, and how to develop it. The success of commanders in the performance of specific functions and especially in the 
leadership of the entrusted team (unit) is therefore often a matter of intuition and a level of social empathy. The assessment of success is the subjective professional experience of an evaluator.

\section{Theoretical basis}

\subsection{Competence in the armies of NATO member countries}

In the armies of NATO member countries, the proceeding pursuant competencies are already implemented, and the competency models are the basis for the creation of education and training programs for soldiers in various positions, especially in commanding positions. In organizational practice, the emphasis is placed on the use of competencies for personnel selection, to determine achieved performance, for the remuneration system and the creation of development plans. [1]. In a similar manner, leadership in the military organization is systematically developed [2-6].

For a successful commander operation, a decisive criterion is the perceived ability to effectively lead subordinates. However, leadership is a difficult process that is not easy to define. This is also the reason why literature lists more than 850 definitions of leadership. The most widespread support can be found for the conceptualization of leadership as a process of social influence leading to the achievement of common goals. [8-10]. The ability to lead is then defined as being relatively stable and having coherent personality traits that promote behaviour to lead not only in one but mostly in a wider range of situations. [11]. A summary of cognitive, interpersonal and personality factors can reliably distinguish an individual and point out a future leader from a person who does not exhibit such characteristics.

Most of the researches in the field of people management are based on the model of the Big Five [12-14], which belongs to the most widespread even in the environment of the armed forces. When selecting for the US Army, for example, a significant relationship between the ability to lead and extraversion has been demonstrated. [15]. Research by Australian officers for leadership prediction lists factors such as: extraversion, openness, and dutifulness [16]. In the US Military Academy at West Point preconditions for leadership were identified as being dutifulness and friendliness [17]. Dutifulness is an important prerequisite for the formation of leadership which is confirmed also by other authors [18]. Further frequently cited predictors for effective leadership are -"dominance"- [1920], communication skills, the ability to build a team, solve problems and make decisions. [21] Some authors emphasize that effective leaders are those who have high credibility. [22]

\subsection{Key competencies and competency models}

\subsubsection{Key competencies}

With the notion of competence files of properties are most often associated as well as the behaviour that is necessary for successful performance [21]. Status "key competencies" emphasize the general nature of the selected competence. Such an approach is traceable e.g. in Richter, whereby the key competencies are beyond the borders of individual specializations [23]. To a higher degree of generality, the lower number of competencies constituted in the competency model are related. The optimum number is generally considered to be a set of 10 to 12 competencies [24]. A higher number may indeed appear as more precise, but such a competency model is becoming less clear.

For better orientation and lucidity, key competencies can be structured in different ways. According to Belz and Siegrist [25], the basic structures of key competencies constitute:

a) Social competencies - teamwork and cooperation ability, the capability to deal with conflict situations, communication skills; 
b) competence in relation to its own personality - the competent treatment of itself, i.e. dealing with its own value, to be one's own manager, the ability to reflect on oneself, to consciously develop one's own values and human image, the ability to assess and further develop oneself;

c) competence in field of methods - a planned way, focusing on the goal of exercising expertise, i.e. to analyse and, develop creative, unorthodox solutions, to structure and classify new information, to put things into context as well as, identify continuity, critically examine in order to achieve innovation and to consider the chances and risks.

As an example for "competence in the methods field" could serve the approach of Prokopenko and Kubr to the "executive competence", which is characterized as follows: "The competence of a manager is their ability to perform a specific function or set of functions, while reaching a certain level of performance" [26] " Understanding to the term of "ability" (in the concept of authors of this text it is rather a "skill") in Prokopenko and Kubr do not differ much from the approach of Veteška, who defines it as "psychological characteristics of personality, which determine the amount of performance in a specific activity" [27].

Distinguishing one's abilities (skills) and overall professional competence may not be too strict in practice if we understand them as part of the overall educational process. From the theoreticians who hold such a view, Brassard should be mentioned, who believes that the skills and professional competence do not stand alongside isolated [28].

\subsubsection{Competency model}

When searching for an appropriate competency model, empirical research plays a crucial role as the basis for the identification of measurable outcomes and the observable effects of success. This way a competency model containing competence can be created with a clearly defined profile, which allows for the objective comparison "of this competency profile with the current professional competence of a worker that actually holds this position"[29].

In terms of the typology of competency models, the authors of this text favour the approach of Hartig and Klieme which relate the typology of competency models to different aspects of competence constructs and the differential diagnosis of individual competencies [30]. It is about a level and structural competency models which are not mutually exclusive but can possibly complement each other.

Level competency models relate to performance, the ability of considered individuals to fulfil the requirements applicable to them on an appropriate level. These models are useful, e.g. in measuring the results of educational processes for the purpose of evaluation, etc. Compared to that, the structural competency models relate to coping with various types of requirements and also to describe the individual differences between competencies.

Also, the significance of those typologies is "appropriately linked to school education by competencies, which is implemented in most of the advanced countries and thus form a system of lifelong learning" [31].

\section{The concept of competence to leadership in the Czech Army}

\subsection{Characteristics}

Competence to leadership is the intention and will of undertaking the role of leaders, desire as well as determination to lead others not only from formal positions but mainly from informal authority. In a military environment, it should be based on the premise that effective leaders are able to repeatedly demonstrate a good level of performance at an appropriate level of classification and according to clearly defined criteria.

Students of the University of Defence are during their studies prepared for a level of 
direct (tactical) leadership. The competence criteria to leadership on a tactical level primarily includes the responsibility for the entrusted unit (team), the ability to manage subordinates, to be able to use formal power, conduct meetings, delegate tasks, build and protect the entrusted unit (team), motivate and promote its individual members, provide them with feedback and develop. This has to do with the fact that after graduation the most of the successful graduates will be assigned to the position of a platoon commander or its equivalent.

When analysing available resources, characterizing the competence to leadership in a way that is usable in the Czech Republic and applicable to the conditions of military leadership within the ACR, the authors of this text came to the conclusion that the criteria set by them correspond best with the characteristics of this competence created for the National Occupations System (NOP) [33].

The underlying assumption was the fact that the level of platoon leader, or its equivalent, complies with the level of so- called "line managers" for civilian occupations.

This fact confirms that ACR personnel training in competence field is being influenced not only by the "internal needs of the education system but also by the reactions to demands of society, in an increasing degree"[32].

\subsection{Realization of the survey research}

The intention of the implemented research survey was to confront the content and structure of partial competencies creating the leadership competence for civilian leading positions in the National Occupations System, with the requirements of the military practice. In the first stage, attention was paid to the position of line manager in order to comply with the systematic approach to create competency models for each level of management in the Czech Army and also for the creation of effective educational and training activities for students of the University of
Defence that are preparing to perform the line position (tactical level) platoon commander or its equivalent.

\subsubsection{Aims and methods of the survey research}

The aim of the research was to determine whether the specified level of competence development to leadership for line managers by the NOP meets the requirements for the performance of the duties of a platoon commander. The required profile of a commander is to be a good manager with leadership qualities.

A basic method of data collection was chosen to interview selected military professionals. For implementation of the method, questionnaire was designed containing nine questions covering the described partial competencies by the NOP (to be responsible for a team, to manage subordinates, to use formal power, ability to lead meetings, delegate tasks, build and protect a team, motivate and encourage team members, provide feedback and develop subordinates) for all levels of the examined competency. Some items had to be operationalised due to its vagueness (e.g., "the uses of formal authority and power in the right way"). Respondents of each characteristic level of partial competencies were rated on a scale of $0-5$, where 0 means: it was the least significant for the performance of the platoon commander and with 5 being: the most significant level. For each item, they could, at their sole discretion, assign any value within this range. To evaluate the results an arithmetic average of the obtained values was used. The higher the value, the more important the characteristic was for the respondents.

\subsubsection{The description of the surveyed sample during research}

The research sample consisted of three groups of respondents. First, the largest group (94) were third-year students doing a full-time study of military courses from the University of Defence. This group can be described as the group with the lowest or no 
professional experience in the role of a military leader at the tactical level, but with adequate theoretical preparation. The second group consisted of members of the army corps non-commissioned officers and warrant officers in the ACR with professional experience as a squad leader, deputy platoon commander or platoon commander (16). This group is characterized by the high level of professional experience and relatively low previous theoretical preparation. The third group consisted of senior officers (25), who have had personal experience being in the role of the platoon leader, as well as a corresponding theoretical background.

Students, non-commissioned officers, and warrant officers were questioned during their winter field training. Students in the third group were questioned during the ongoing course of the General Staff.

The last two groups were combined into a VZP group - non-student (for a small frequency and due to minimum deviations) in the monitored factors for evaluation. For large differences in the size of the groups, the results will not be compared with each other between the groups of respondents.

\subsubsection{The results of the survey research}

In accordance with the research, the following research questions were created:

1. For the performance of the platoon commander, according to military professionals, it is sufficient to achieve Level 3 by the NOP to develop the competence of leadership?
2. What level of leadership competence is for a platoon commander is different for groups of respondents?

3. Are there any characteristics belonging to the competence of leadership, which does not contain NOP and are important for the performance of a platoon commander?

Respondents considered the selected level for partial competencies rather important for the leadership competence of a platoon commander, all items were reported by all groups with a value higher than 3 . To every partial competence in level 3, by the NOP classification, they did not give the same importance. Both groups believed enhancing team performance, the proper use of formal power and authority, supporting others in their development and the regular review of the goals and aims realization was most important.

As shown in the table, respondents in some partial competencies forming the competencies for leadership, demand a higher level than is specified by the NOP. Level 4 by the NOP requires the competence of responsibility for the team, the ability to delegate tasks, to motivate subordinates, while level 5 requires the competence to provide feedback and develop subordinates.

In the offered loose answers respondents did not add significant or substantively important parts of competencies for leadership. 


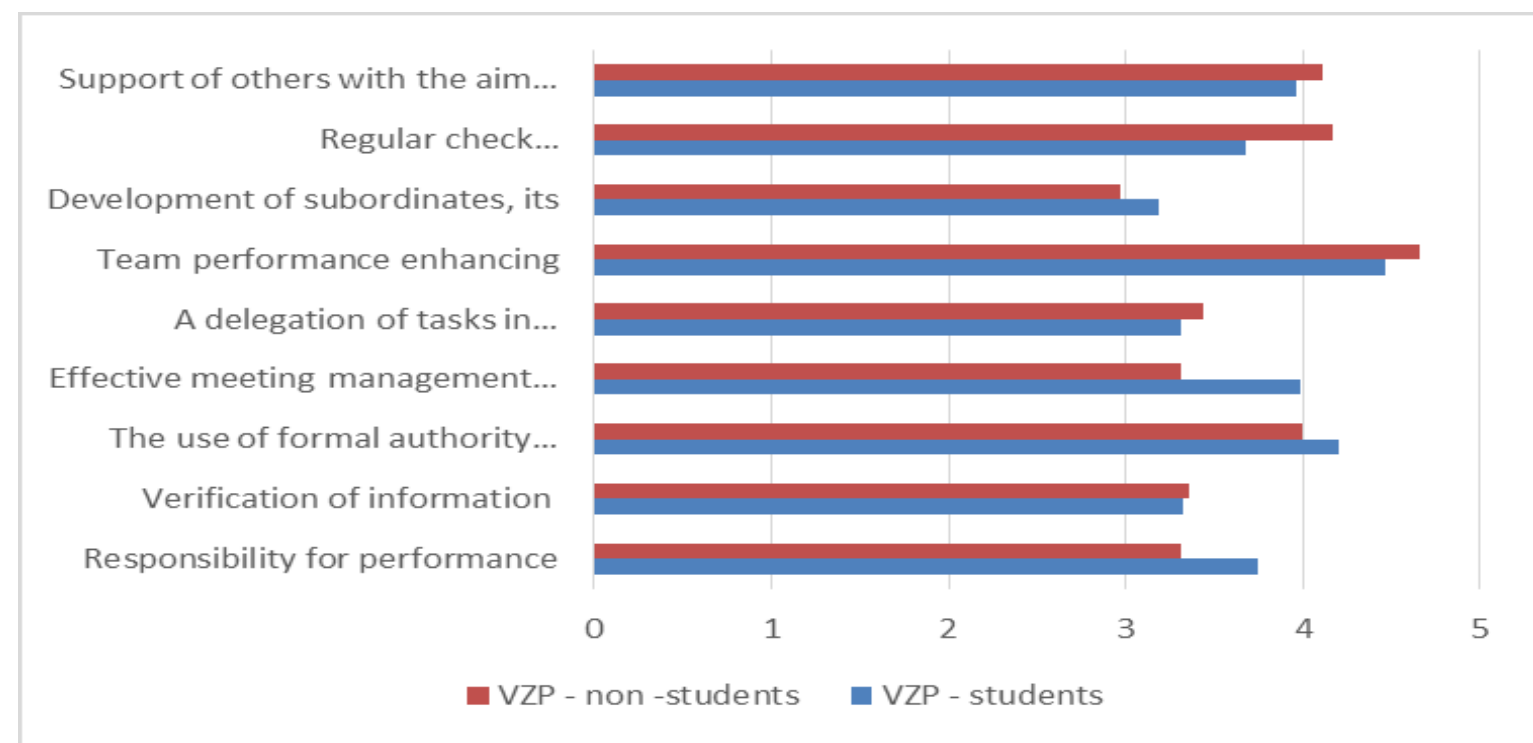

Image 1: The evaluation of partial competencies significance - the position of platoon commander Level 3

\begin{tabular}{|c|c|c|c|c|c|c|c|c|c|}
\hline & $\begin{array}{l}\overrightarrow{0} \\
\stackrel{0}{0} \\
0 \\
0 \\
0 \\
0 \\
0 \\
0 \\
0 \\
0 \\
0 \\
0 \\
0 \\
0 \\
0 \\
0\end{array}$ & 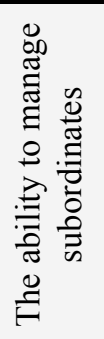 & 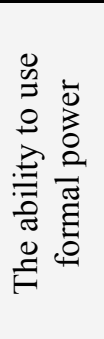 & 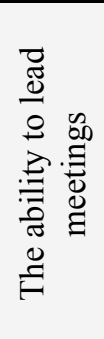 & 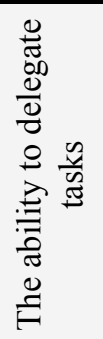 &  & 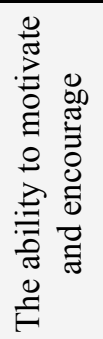 & 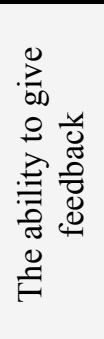 & 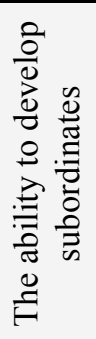 \\
\hline $\begin{array}{l}\text { VZP - } \\
\text { students }\end{array}$ & 4 & 1 & 3 & 3 & 4 & 3 & 4 & 5 & 5 \\
\hline $\begin{array}{c}\mathrm{VZP}- \\
\text { non- } \\
\text { students }\end{array}$ & 4 & 1 & 3 & 3 & 4 & 3 & 4 & 5 & 5 \\
\hline NSP & 3 & 3 & 3 & 3 & 3 & 3 & 3 & 3 & 3 \\
\hline
\end{tabular}

Table 1: The preferred level of partial competencies - Platoon Commander Position

\section{Conclusions}

Competence for leadership for commanding positions is necessary to understand as the key competence, belonging to social competence and structured. Based on the content analysis of competence to leadership in literature and the NOS, the authors came to the conclusion that for some levels it is necessary to specify a description of partial competencies for the original civil line management and create its own classification of leadership competence levels for all levels of management in a military environment.

The completed research survey shall be perceived as piloting since there has been no other research with similar conditions conducted for the Ministry of Defense of the Czech Republic. It emerged that even for the Platoon Commander Position, some partial competencies shall be developed at the highest level. 


\section{References}

[1] Cheng, M., Dainty, A., \& Moore. Towards a multidimensional competency-based managerial performance framework: A hybrid approach. Journal of Managerial Psychology, Vol. 20, No. 5, pp. 380-396, 2005.

[2] Kirkland, F. R., Bartone, P. T., \& Marlove, D. H. Commanders' Priorities and Psychological Readiness. Armed Forces and Society, Vol. 19, No. 4, pp. 579-598, 1993.

[3] Myers, S. R. \& Groh, J. The Future of Strategic Leader Development at the U. S. Army War College [online]. 1. 1. 2010 [cit. 31. 1. 2017]. Integral Leadership Review, 10, 1. 2010. Available from: http://integralleadershipreview.com/12005-article/

[4] Roberts, M. K. Strengths Based Leadership Theory and Development of Subordinate Leaders. Military Review, No. 2, pp. 33-41, 2014.

[5] Wojack, A. Is Experience the Missing Link in Junior Officer Development? Military Review, No. 2, pp. 33-41, 2014.

[6] Wortei, E., \& Bosch, J. Strenghtening Moral Competence: A "Train the Trainer" Course on Military Ethics. Journal of Military Ethics, Vol. 10, No. 1, pp. 17-35, 2011.

[7] Bennis, W. G. On becoming a leader (4th ed.). New York: Basic Books March, 2009.

[8] Kaiser, R., McGinnis, \& Overfield, D. The how and the what of leadership. Consulting Psychology Journal: Practice and Research, Vol. 64, No. 2, 119-135, 2012.

[9] Spendlove, M. Competencies for effective leadership in higher education. International Journal of Educational Management, Vol. 21, No. 5, pp. 407-417, 2007.

[10] Yukl, G. Effective Leadership Behavior: What We Know and What Questions Need More Attention. Academy of Management Perspectives, Vol. 26, No. 4, pp. 66-85, 2012.

[11] Zaccaro, S. J. Trait-based perspectives of leadership. American Psychologist, Vol. 62, No. 1, pp. 6-16, 2007.

[12] Judge, T. A., \& Bono, J. E. Five-factor model of personality and transformational leadership. Journal Of Applied Psychology, Vol. 85, No. 5, pp. 751-765, 2000.

[13] Ng, K., Ang, S., \& Chan, K. Personality and leader effectiveness: A moderated mediation model of leadership self-efficacy, job demands, and job autonomy. Journal Of Applied Psychology, Vol. 93. No. 4, pp. 733-743, 2008.

[14] Barrick, M., \& Mount, M. The big five personality dimensions and job performance. Personnel Psychology, Vol. 44, No. 1, pp. 1-26, 1991.

[15] Thomas, J. L., Dickson, M. W., \& Bliese, P. D. Using personal values and motives to predict success as a leader in the US Army Reserve Officer Training Corps. Leadership Quarterly, No. 12, pp. 181-196, 2001.

[16] McCormack, L., \& Mellor, D. The role of personality in leadership: An application of the five-factor model in the Australian military. Military Psychology, No. 14, pp. 179-197, 2002.

[17] Bartone, P. T., Snook, S. A., \& Tremble, T. R. Cognitive and personality predictors of leader performance in West Point cadets. Military Psychology, No. 14, pp. 321-338, 2002.

[18] Taggar, S., Hackew, R., \& Saha, S. Leadership emergence in autonomous work teams: antecedents and outcomes. Personnel Psychology, Vol. 52, No. 4, pp. 899-926, 1999.

[19] Bradley, J. P., Nicol, A. A. M., Charbonneau, D., \& Meyer, J. P. Personality correlates of leadership development in Canadian forces officer candidates. Canadian Journal of Behavioral Science, No. 34, pp. 92-103, 2002.

[20] Rueb, J., Erskine, D., \& Holly J. Intelligence, dominance, masculinity, and selfmonitoring: Predicting leadership emergence in a military setting. Military Psychology, Vol. 20, No. 4, pp. 237-252, 2008. 
[21] Abraham, S. E., Karns, L. A., Shaw, K., \& Mena, M. A. Managerial competencies and the managerial performance appraisal process. The Journal of Management Development, Vol. 20, No. 9, pp. 842-852, 2001.

[22] Hogan, R., \& Kaiser, R. What we know about leadership. Review of General Psychology, Vol. 9, No. 2, pp. 169-180, 2005.

[23] Richter, Ch. Schlüsselqualifikationen. München: Alling, 1995

[24] Hroník, F. Hodnocení pracovníků. Praha: Grada Publishing, 2006.

[25] Belz, H., \& Siegrist, M. Klíčové kompetence a jejich rozvíjení. Praha: Portál, 2001.

[26] Prokopenko, J., \& Kubr, M. et al. Vzdělávání a rozvoj manažerů. Praha: Grada Publishing, 1996.

[27] Veteška, J. Sociální a ekonomické podmínky vzdělávání. In Veteška, J. et al. Teorie a praxe kompetenčního př́stupu ve vzdělávání. Praha: Educa Service, pp. 41-66, 2011.

[28] Brassard, W. Wege zur beruflichen Mündigkeit. Teil 1. Weinheim: Didaktische Grundlagen, 1992.

[29] Tureckiová, M. Řizení a rozvoj lidí ve firmách. Praha: Grada Publishing, 2004.

[30] Hartig, J., \& Jude, N. Empirische Erfassung von Kompetenzen und psychometrische Kompetenzmodelle. In J. Hartig \& E. Klieme, (ed.) Möglichkeiten und Voraussetzungen technologiebasierter Kompetenzdiagnostik, (pp. 17-36). Berlin: BMBF, 2007.

[31] Veteška, J. Přehled andragogiky: úvod do studia vzdělávání a učení se dospělých. Praha: Portál, 2016.

[32] Kubínyi, L. Monitoring interního trhu práce. In Veteška, J. et al. Celoživotní učení pro všechny-výzva 21. století. Praha: UJAK, pp. 329-338, 2014

[33] http://www.katalog.nsp.cz/Napoveda/Prilohy_Manualu_NSP/Priloha_c10_manualu.pdf 